Original Research Paper

\title{
Nano-Diamond Hybrid Materials for Structural Biomedical Application
}

\author{
${ }^{1}$ Raffaella Aversa, ${ }^{2}$ Relly Victoria V. Petrescu, ${ }^{1}$ Antonio Apicella and ${ }^{2}$ Florian Ion T. Petrescu \\ ${ }^{1}$ Advanced Material Lab, Department of Architecture and Industrial Design, \\ University of Campania, 81031 Aversa (CE) Italy \\ ${ }^{2}$ Bucharest Polytechnic University, Bucharest, (CE) Romania
}

Article history

Received: 02-02-2017

Revised: 02-03-2017

Accepted: 09-03-2017

Corresponding Author:

Florian Ion T. Petrescu

Bucharest Polytechnic

University, Bucharest, (CE)

Romania

Email: fitpetrescu@gmail.com

\begin{abstract}
The development of new diamond based bio-mechanically active hybrid nano-structured scaffolds for cartilage cells tissue engineering are proposed in this study. Innovative tissue engineering biomimetic materials based on hydrogel have shown attractive physical, biological and mechanical properties in several biomedical applications. A highly biocompatible novel hybrid material based on nanodiamonds and hydrophilic poly-(hydroxyl-ethyl-methacrylate) (pHEMA) is proposed. The aim of this paper is to describe the chemical and analytical procedures for the preparation of nanofilled hybrid composites possessing biomimetic, osteoconductive and osteoinductivity properties that can be useful in the design of bio-mechanically active innovative bone scaffolding systems for stem cell differentiation and growth. A more rigid and rubber transparent hybrid nano-composites are predicted to posses improved mechanical strength overwhelming one of the major weaknesses of hydrogels, which is due their poor mechanical characteristics, for applications in biomedical structural application.
\end{abstract}

Keywords: Biomaterials, Bioactive Scaffolds, Bioengineering, Biomedical

\section{Introduction}

Biomaterials are today playing a central role in tissue engineering and regenerative medicine applications. The collaboration between engineers, chemists, physicists, biologists and physicians speeded up research in this field, allowing a faster development of new biomaterials and technologies to overcome the challenges and to front the various needs of each specific tissue-engineering field. Although many biomaterials applications are far from clinical translation, regenerative medicine has greatly advanced during the last years and it bodes well for future translation of research discoveries from bench-to-thebedside, in order to gain in life expectancy and life quality (Montheard et al., 1992; Filmon et al., 2002; Davis et al., 1991; Kabra et al., 1991; Apicella et al., 1993; Peluso et al., 1997; Petrescu et al., 2016a; 2016b; 2016c; 2016d; 2016e).

Among the different allotropic forms of Carbon, graphite is the more thermodynamically stable at ambient temperatures and pressures, while diamond, in these conditions, may exist only in its metastable state. In fact, due to the high-energy barrier that separated the graphitic $\mathrm{sp}_{2}$ and diamond $\mathrm{sp}_{3}$ configurations (Fig. 1A and $\mathrm{B})$, high temperatures and pressures in presence of catalysts are needed to transform graphite in diamond.
Nevertheless, a third parameter (surface area) becomes crucial at the nanoscale level and it become relevant in the definition of the system equilibrium energy levels: At this nano-dimensions, the Gibbs free energy becomes dependent on the contribution of the surface energy, leading to changes in the thermodynamic equilibrium phase diagram (Barnard et al., 2003; Barnard and Sternberg, 2007; Viecelli et al., 2001). Tetrahedral hydrocarbons in the form of nano-diamonds of $3 \mathrm{~nm}$ have been demonstrated by atomistic models to be more stable than poly-aromatics graphite (Fig. 1C).

In addition, a more complex morphological structure is generated at the nanodiamond interface; Barnard and Sternberg (2007) reported that cuboctahedral clusters presented a transition from $\mathrm{Sp}_{3}$ to $\mathrm{Sp}_{2}$ carbons at the surfaces of aggregations of 1.0-3.0 nm.

On this morphological transition at the interface, it has been recently demonstrated by Xiao et al. (2014) that reversible nanodiamond-graphitic carbon onion like phase transformation can occur even at room temperature and pressure leading to the formation of diamond cores with graphitic shells (bucky-diamond) (Fig. 1C) (Barnard and Sternberg, 2007). 


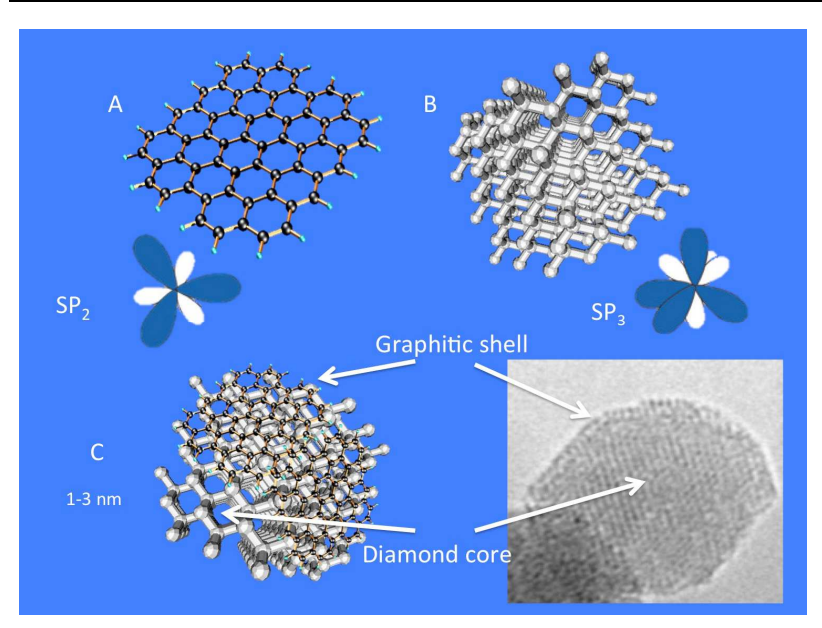

Fig. 1. (A) Graphite ( $\mathrm{SP}_{2}$ hybridization) and (B) Diamond ( $\mathrm{SP}_{3}$ hybridization) Carbon allotropic forms. (C) Nanodiamond core with external graphitic shell (TEM of a nanodiamond atom structure, right side)

These findings allowed us to understand that the nanodiamond surfaces can be then easily modified through the chemistry of graphitic carbon in many different chemical methods, such are the Diels-Alder cycloaddition reactions between conjugated diene and dienophile, to form functionalised cyclohexene systems (Jarre et al., 2011).

This new class of materials based on Carbon $\mathrm{Sp}_{2}$ and $\mathrm{Sp}_{3}$ nanocrystalline structures is very attractive for future nanotechnological development in biomedical structural applications. Nanocrystalline particles, which are often named detonation nanodiamond and characterized by sizes of 3-6 nm, are produced by detonation of carbon explosive materials (Danilenko, 2004; Greiner et al., 1988; Ozawa et al., 2007; Chang et al., 2008).

Detonation nanodiamond have been initially utilized in applications such as galvanic coatings, polishing systems, polymer nano-composities, lubricants. New niche applications, however, are recently developing; magnetic recording, adsorbents, diamond ceramics production, coatings in field emission devices, catalyzes of heterogeneous catalysts and in fuel cells as protonconducting nanocomposite membranes. Preliminary investigation demonstrated that detonation nanodiamonds are non-toxic and biocompatible, making them very attractive for bio-medical applications considering its easy controllable rich surface chemistry.

However, it has been reported that detonation nanodiamonds may be characterized by different levels of purity and by the presence of several undesired functional groups/elements at the diamond particles surface, while high surface chemical purity and uniformity surfaces are needed for biomedical applications (Lai and Barnard, 2011a; 2011b). A simple purification method utilizes oxidation procedures. Depending on the type of procedure, the detonation powder of different levels of purities and specific surface characteristics can be obtained. The fraction of the Carbon that is not present as diamond can be purified up to $95 \%$ by weight by oxidation at high temperatures in air/Ozone atmosphere (Osswald et al., 2006; Shenderova et al., 2011).

Oxidation, while removing undesired processing functional compunds at nanodiamond surfaces, forms oxygen-containing groups, such are anhydrides and carboxylic acids (Shenderova et al., 2011).

The simple air/ozone purification, then, produces carboxylated nano-diamond with highly reactive and hydrophilic surface $\mathrm{OH}$ terminations appropriate in biomedical applications (Krueger et al., 2008; Kruger et al., 2006).

Diamond and glassy carbon has been recognized in literature, however, the toxicity of nano-diamonds remains a real concern (Schrand et al., 2009b). In vitro and in vivo studies are still needed to evaluate characteristics such as in vivo mechanical and physiological behaviours (Zhang et al., 2011; Schrand et al., 2009a; 2009b; Yuan et al., 2010; Mohan et al., 2010) as well as cell viability or undesired gene modification activity.

Previous investigations of our group have shown that high level of biocompatibility and bioactivity has been observed for nano-composite materials made combining amorphous silica nanoparticles of about $7 \mathrm{~nm}$.

Bioengineering and nanotechnology applied to micro and nano-materials are being progressively adopted as emerging solutions in 2D (coatings) and 3D applicatons (scaffolds) (Sorrentino et al., 2007; Aversa et al., 2016a). Conclusively, such micro and nano-technologies have shown a high potential for usage in advanced manufacture models finalized to the growth of well-organized tissue engineered structures (Petrescu and Calautit, 2016a; 2016b).

Bone scaffolds have been always a relevant matter for research since they should provide sufficiently rigid but resilient network to be an ideal scaffold that momentarily substitute the damaged bone. Nevertheless, they should be able at the same time to readily biodegrade after the formation of the new tissue in order to fully integrate with it (Kabra et al., 1991; Montheard et al., 1992; Peluso et al., 1997; Schiraldi et al., 2004; Buzea et al., 2015; Aversa et al., 2016a; 2016b; 2016c; 2016d; 2016e; 2016f; 2016g; 2016h; 2016i; 2016j; 2016k; 2016l; 2016m; 2016n; 2016o).

Our research group have investigated hydrogel hybrid composites, based on the association of pHEMA with Amorphous Pyrogenic Silica that were tested for the intake of water, the balance of swelling in water and in saline solution and for the cell response with assays of adhesion, morphology, distribution, using fibroblasts and osteoblasts as cell-models. The presence of the silica makes this biomaterials excellent, with respect to the pHEMA alone. Good properties of 
osteoinduction have been also observed for differentiation of dental pulp stem cells (Abdul-Razzak et al., 2012; Ajith et al., 2009; Ahmed et al., 2011; Apicella and Hopfenberg, 1982; Atasayar et al., 2009; Babaev et al., 2010; Chow et al., 2010; Comerun, 1986; Covic et al., 2007; Frost, 1964; 1990; 1994; 2004; Gramanzini et al., 2016; Holley et al., 1970; Krueger and Boedeker, 2008; Nicolais et al., 1984; Petrescu et al., 2015; Prashantha et al., 2001; Raffaella and Antonio, 2016; Raffaella et al., 2016; Sorrentino et al., 2009; Töyräsa et al., 2001; Wolff, 1892).

Silica nano-composites synthesized in our laboratory, which contained highly-bioactive amorphous fumed, have been found to represent a new class of hybrid polymeric-ceramic scaffolding materials able to mimic the mechanical behavior of the bone. Micro-foamed self assembled nanostructured composite have been tested as scaffold that showed osteoblast grow ability and stem cells differentiation (Marrelli et al., 2015).

\section{Materials and Methods}

\section{Materials}

The monomer 2-hydroxyethylmethacrylate (HEMA), obtained from Sigma-Aldrich Chemicals Co., St. Louis, MO, USA, has been used for the polymerization of a hydrophilic composite matrix. Raw detonation nanodiamonds (Aldrich, $\geq 97 \%$ ), which mean diameter ranged between 3-5 $\mathrm{nm}$ and which specific surface area was of $400 \mathrm{~m}^{2} \cdot \mathrm{g}^{-1}$, were utilized as bioactive filler. HEMA monomers (Fig. 2) have been thermally polymerized in presence of an initiator for radical polymerization, namely, the $\alpha-\alpha$ ' azoisobutyrronitrile (AIBN), obtained from Fluka Milan, Italy. In a preliminary test of nanocomposite preparation, the nanodiamond were mixed in the ratio of $5 \%$ by volume with the HEMA monomers and degassed. The mixture was then poured into $2.0 \mathrm{~mm}$ thick planar moulds before polymerization in the oven that was hold at the controlled temperature of $60^{\circ} \mathrm{C}$ for $24 \mathrm{~h}$. The nano-composite plates were subjected to a final post-cure at $90^{\circ} \mathrm{C}$ for $1 \mathrm{~h}$.

\section{Results and Discussion}

Nano-diamonds dispersion in the HEMA monomer resulted in a transparent and clear, light grey colour, solution. This behaviour testified the good dispersion and absence of nanofiller clusters. The good dispersion ability of the Oxidized Detonation nano-diamonds in the reacting mixture could be attributed to the strong interactions between the oxygen containing functional groups on the filler and the HEMA hydroxyl that led to the preferential self-assembly orientation of the monomers toward the nano-filler surface (Fig. 3 detail upper left). The successive polymerization of the HEMA resulted in a still clear and transparent glassy solid. The good dispersion of the nano-diamond was reasonably preserved after the polymerization (Abdul-Razzak et al., 2012; Ajith et al., 2009; Ahmed et al., 2011; Apicella and Hopfenberg, 1982; Atasayar et al., 2009; Babaev et al., 2010; Chow et al., 2010; Comerun, 1986; Covic et al., 2007; Frost, 1964; 1990; 1994; 2004; Gramanzini et al., 2016; Holley et al., 1970; Krueger and Boedeker, 2008; Nicolais et al., 1984; Petrescu et al., 2015; Prashantha et al., 2001; Raffaella and Antonio, 2016; Raffaella et al., 2016; Sorrentino et al., 2009; Töyräsa et al., 2001; Wolff, 1892).

A similar self assembly condition has been described by Aversa et al. (2016a; 2009) to occur between amorphous nanosilica particles, which are characterized by a disordered structure containing many not regular rings and not bridging Oxygen atoms (red in Fig. 4) and the same HEMA monomer.

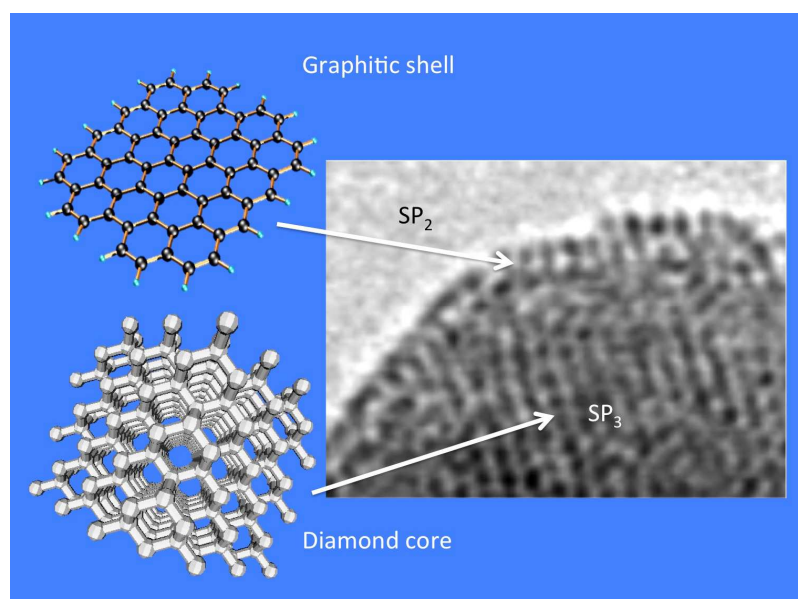

Fig. 2. bucky-diamond: A 2-3-nm diamond core surrounded by a fullerene-like carbon network right TEM of a diamond-graphene transition)

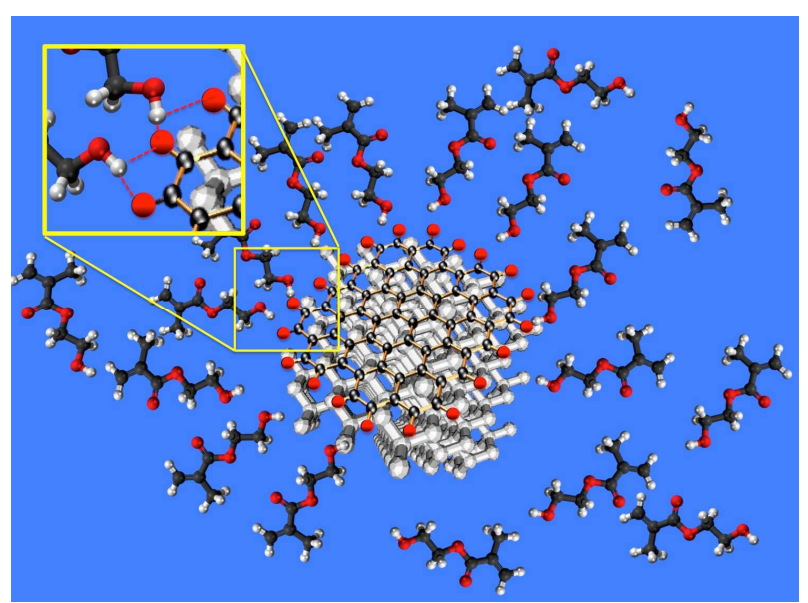

Fig. 3. Behaviour of HEMA monomers in presence of Detonation Nano_Diamond 


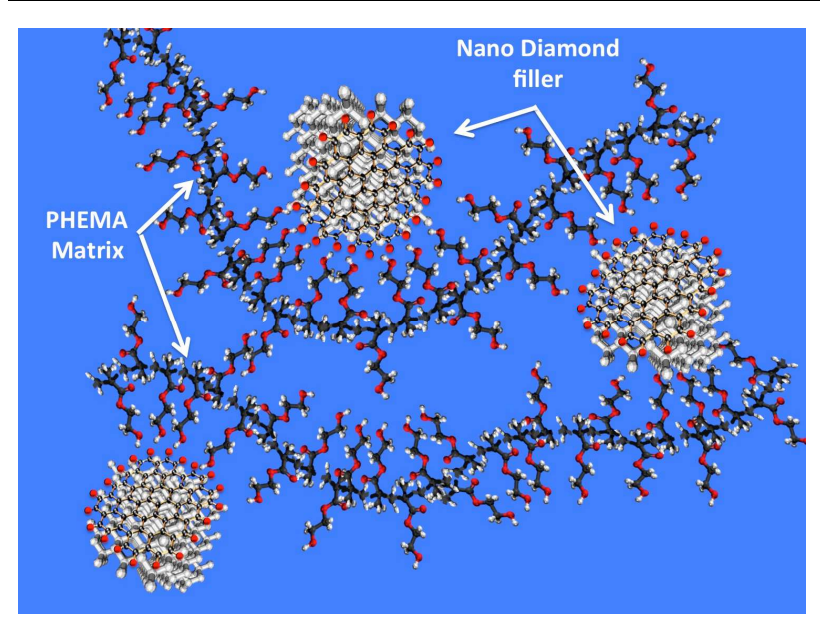

Fig. 4. Hypothesized Nano-Diamonds pHEMA self assembled structure

The polymerization of HEMA/amorphous nanosilica mixtures leads to the formation of a hybrid nanostructured material with particularly peculiar and improved mechanical properties and biocompatibility (Aversa et al., 2016b).

In the case of nono-diamond filled pHEMA, the same improvement of the mechanical properties and biocompatibility could be then expected. However, the expected mechanical properties enhancements could be much more relevant due to diamond much higher rigidity and strength (Azo tech spech).

The shear Modulus of synthetic diamond, which ranges from 440 to $470 \mathrm{GPa}$ (Azo tech information), is almost 15 times higher than that of Silica, which ranges from 27.9 to 32.3 (Azo tech spec.). According to this information and considering the mechanical shear behaviour of the analogous hybrid materials based on silica nanoparticles (Aversa et al., 2016c), the behaviour of the variation of the shear modulus as a function of the diamond nanoparticles volume fraction in the hybrid material could be evaluated Fig. 5 .

According to Aversa et al. (2016e), strong plasticization is induced by the physiological solutions sorption in the hybrid pHEMA-nanosilica composite.

It has been described by Aversa et al. (2016f; 2009) that the measured shear modulus of the Nanosilica hybrid composites at different filler content was not described by the classical Halpin and Kardos (1976) equation that is commonly utilized for the particulate composites. The hybrid nano-composites showed a linear dependency at increasing contents of nanosilica filler. This occurrence confirmed the hybrid nature of the nanosilica filled $\mathrm{pHEMA.}$

At nano-diamond volumetric fractions ranging from 2 to and $5 \%$, the shear moduli were comparable to those of the cortical bone (10-20 GPa, reported as grey area in Fig. 5). Similar results have been described by Aversa et al. (2016g; 2009) to occur for nanosilica hybrids at higher loading ranging from 15 to $30 \%$ by volume.

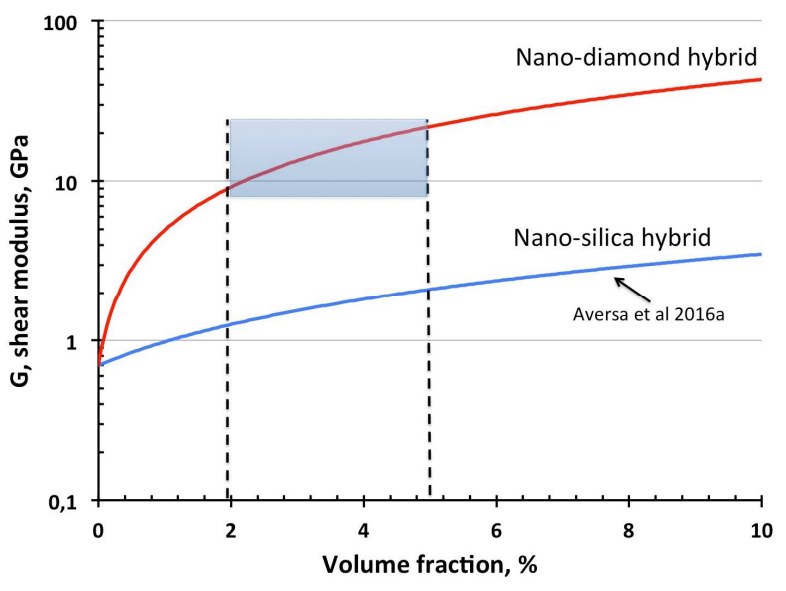

Fig. 5. Comparison between the elastic shear moduli of the experimentally measured Nanosilica-pHEMA hybrids (blue line) and the hypothesized Nano-Diamonds pHEMA self assembled Hybrid

\section{Conclusion}

New bioactive nanodiamond-polymeric hybrid materials to be used as biomechanical active scaffold materials showing potential improved bone scaffold mineralization and ossification properties have been developed by following a biomimetic approach.

The new nanocomposites based on poly-HydroxylEthyl-Methacrylate (pHEMA) filled with detonation nanodiamonds could be identified as a biomimetic biomaterial at filler concentration up to $5 \%$ by volume. Moreover, this glassy hybrid material swells to rubber in presence of aqueous physiological solution picking-up more than $40 \%$ of water. At very low levels of nano-diamond loading, the mechanical behaviour of the proposed hybrid materials could be comparable with that of bone when in the glassy state, or to that of cartilage and ligaments when in the rubbery state following water sorption.

The use as scaffolds of these mechanically compatible hybrid hydrogels is expected to improve the adaptation mechanisms of the bone by introducing an active interface that could ameliorate biomimetics by correctly reproducing cartilage and ligaments biomechanical functions (Schwartz-Dabney and Dechow, 2003; Perillo et al., 2010; Apicella et al., 2010; 2011; 2015; Aversa et al., 2016h; 2009).

Adaptive properties of bone could benefit of use of biomechanically compatible and bioactive scaffold biomaterials associated to new design odontostomatological prostheses.

\section{Acknowledgement}

We acknowledge and thank Mr Taher M. AbuLebdeh, Associate Prof at North Carolina A and T State 
Univesity, United States and Mr Muftah H. El-Naas PhD MCIC FICCE QAFCO Chair Professor in Chemical Process Engineering Gas Processing Center College of Engineering Qatar University and Ms Shweta Agarwala, Senior Research Scientist at Singapore Center for 3D Printing Nanyang Technological University Singapore for their suggestions and comments. The Authors acknowledge Liquid Metals Technologies Inc, Ca USAthat kindly supply the samples for the characterization and Dr Francesco Tatti (FEI Company Application Specialist SEM-SDB) for its contribut in the preparation of this paper experiments and analyses. The authors would like to appreciate the facilities and assistance provided by the Advanced Technology Dental Research Laboratory, Faculty of dentistry, King Abdul Aziz University. The authors would also appreciate the research technicians, Basim Al Turki and Fahad Al Othaibi for their cooperation.

\section{Funding Information}

This research was partially funded by Italian Ministry of University and Research with the project FIRB "Future in Research 2008", \# RBFR08T83J.

\section{Author's Contributions}

All the authors contributed equally to prepare, develop and carry out this manuscript.

\section{Ethics}

This article is original and contains unpublished material. The corresponding author confirms that all of the other authors have read and approved the manuscript and no ethical issues involved.

\section{References}

Abdul-Razzak, K., K. Alzoubi, S. Abdo and W. Hananeh, 2012. High-dose vitamin C: Does it exacerbate the effect of psychosocial stress on liver? Biochemical and histological study. Exp. Toxicol. Pathol., 64: 367-371. DOI: 10.1016/j.etp.2010.09.011

Ahmed, E., H. Omar, S. Elghaffar, S. Ragb and A. Nasser, 2011. The antioxidant activity of Vitamin C, DPPD and 1-cysteine against Cisplatin-induced testicular oxidative damage in rats. Food Chem. Toxicol., 49: 1115-1121. DOI: 10.1016/j.fct.2011.02.002

Ajith, T.A., G. Abhishek, D. Roshny and N.P. Sudheesh, 2009. Co-supplementation of single and multi doses of vitamins $\mathrm{C}$ and $\mathrm{E}$ ameliorates cisplatin-induced acute renal failure in mice. Exp. Toxicol. Pathol., 61: 565-571. DOI: 10.1016/j.etp.2008.12.002
Apicella, A., B. Cappello, M.A. Del Nobile, M.I. La Rotonda, G. Mensitieri and L. Nicolais, 1993. Poly(Ethylene oxide) (PEO) and different molecular weight PEO blends monolithic devices for drug release. Biomaterials, 142: 83-90. DOI: 10.1016/0142-9612(93)90215-N

Apicella, A. and H.B. Hopfenberg, 1982. Water-swelling behavior of an ethylene-vinyl alcohol copolymer in the presence of sorbed sodium chloride. J. Applied Polymer Sci., 27: 1139-1148.

DOI: 10.1002/app.1982.070270404

Apicella, D., R. Aversa, M. Tatullo, M. Simeone and J. Syed et al., 2015. Direct restoration modalities of fractured central maxillary incisors: A multi-levels validated finite elements analysis with in vivo strain measurements. Dental Mater., 31: e289-e305.

DOI: $10.1016 /$ j.dental.2015.09.016

Apicella, D., M. Veltri, P. Balleri, A. Apicella and M. Ferrari, 2011. Influence of abutment material on the fracture strength and failure modes of abutmentfixture assemblies when loaded in a bio-faithful simulation. Clin. Oral Implants Res., 22: 182-188. DOI: $10.1111 /$ j.1600-0501.2010.01979.x

Apicella, D., R. Aversa, E. Ferro, D. Ianniello and A. Apicella, 2010. The importance of cortical bone orthotropicity, maximum stiffness direction and thickness on the reliability of mandible numerical models. J. Biomed. Mater. Res. Part B Applied Biomater., 93: 150-163. DOI: 10.1002/jbm.b.31569

Atasayar, S., H. Gürer-Orhan, B. Gürel, G. Girgin and H. Özgünes, 2009. Preventive effect of aminoguanidine compared to vitamin $\mathrm{E}$ and $\mathrm{C}$ on cisplatin-induced nephrotoxicity in rats. Exp. Toxicol. Pathol., 61: 23-32. DOI: $10.1016 /$ j.etp.2008.04.016

Aversa, R., D. Apicella, L. Perillo, R. Sorrentino and F. Zarone et al., 2009. Non-linear elastic threedimensional finite element analysis on the effect of endocrown material rigidity on alveolar bone remodeling process. Dental Mater., 25: 678-690. DOI: 10.1016/j.dental.2008.10.015

Aversa, R., F.I.T. Petrescu, R.V. Petrescu and A. Apicella, 2016a. Biomimetic FEA bone modeling for customized hybrid biological prostheses development. Am. J. Applied Sci., 13: 1060-1067. DOI: 10.3844/ajassp.2016.1060.1067

Aversa, R., D. Parcesepe, R.V. Petrescu, G. Chen and F.I.T. Petrescu et al., 2016b. Glassy amorphous metal injection molded induced morphological defects. Am. J. Applied Sci., 13: 1476-1482. DOI: 10.3844 ajassp.2016.1476.1482

Aversa, R., R.V. Petrescu, F.I.T. Petrescu and A. Apicella, 2016c. Smart-factory: Optimization and process control of composite centrifuged pipes. Am. J. Applied Sci., 13: 1330-1341. DOI: 10.3844 ajassp.2016.1330.1341 
Aversa, R., F. Tamburrino, R.V. Petrescu, F.I.T. Petrescu and M. Artur et al., 2016d. Biomechanically inspired shape memory effect machines driven by muscle like acting NiTi alloys. Am. J. Applied Sci., 13: 1264-1271.

DOI: 10.3844/ajassp.2016.1264.1271

Aversa, R., E.M. Buzea, R.V. Petrescu, A. Apicella and M. Neacsa et al., 2016e. Present a mechatronic system having able to determine the concentration of carotenoids. Am. J. Eng. Applied Sci., 9: 1106-1111. DOI: 10.3844/ajeassp.2016.1106.1111

Aversa, R., R.V. Petrescu, R. Sorrentino, F.I.T. Petrescu and A. Apicella, 2016f. Hybrid ceramo-polymeric nanocomposite for biomimetic scaffolds design and preparation. Am. J. Eng. Applied Sci., 9: 1096-1105. DOI: 10.3844/ajeassp.2016.1096.1105

Aversa, R., V. Perrotta, R.V. Petrescu, C. Misiano and F.I.T. Petrescu et al., 2016g. From structural colors to super-hydrophobicity and achromatic transparent protective coatings: Ion plating plasma assisted $\mathrm{TiO}_{2}$ and $\mathrm{SiO}_{2}$ nano-film deposition. Am. J. Eng. Applied Sci., 9: 1037-1045.

DOI: 10.3844/ajeassp.2016.1037.1045

Aversa, R., R.V. Petrescu, F.I.T. Petrescu and A. Apicella, 2016h. Biomimetic and evolutionary design driven innovation in sustainable products development. Am. J. Eng. Applied Sci., 9: 1027-1036. DOI: 10.3844/ajeassp.2016.1027.1036

Aversa, R., R.V. Petrescu, A. Apicella and F.I.T. Petrescu, 2016i. Mitochondria are naturally micro robots-a review. Am. J. Eng. Applied Sci., 9: 991-1002. DOI: 10.3844/ajeassp.2016.991.1002

Aversa, R., R.V. Petrescu, A. Apicella and F.I.T. Petrescu, 2016j. We are addicted to vitamins $\mathrm{C}$ and EA review. Am. J. Eng. Applied Sci., 9: 1003-1018. DOI: $10.3844 /$ ofsp. 10872

Aversa, R., R.V. Petrescu, A. Apicella and F.I.T. Petrescu, 2016k. Physiologic human fluids and swelling behavior of hydrophilic biocompatible hybrid ceramo-polymeric materials. Am. J. Eng. Applied Sci., 9: 962-972. DOI: 10.3844/ofsp.10850

Aversa, R., R.V. Petrescu, A. Apicella and F.I.T. Petrescu, 20161. One can slow down the aging through antioxidants. Am. J. Eng. Applied Sci., 9: 1112-1126. DOI: 10.3844/ajeassp.2016.1112.1126

Aversa, R., R.V. Petrescu, A. Apicella and F.I.T. Petrescu, 2016m. About homeopathy or «Similia Similibus Curentur $\gg$. Am. J. Eng. Applied Sci., 9: 1164-1172. DOI: 10.3844/ajeassp.2016.1164.1172

Aversa, R., R.V. Petrescu, A. Apicella and F.I.T. Petrescu, 2016n. The basic elements of life's. Am. J. Eng. Applied Sci., 9: 1189-1197.

Aversa, R., F.I.T. Petrescu, R.V. Petrescu and A. Apicella, 2016o. Flexible stem trabecular prostheses. Am. J. Eng. Applied Sci., 9: 1213-1221. DOI: 10.3844/ajeassp.2016.1213.1221
Raffaella, A. and A. Antonio, 2016. Near critical carbon dioxide sorption induced crystallization in PET. Am. J. Eng. Applied Sci., 9: 846.853.

DOI: 10.3844 /ajeassp.2016.846.853

Raffaella, A., S. Roberto and A. Antonio, 2016. Biomechanically active ceramic-polymeric hybrid scaffolds for tissue engineering. Adv. Biol. Sci. Res., 16: 308-318. DOI: 10.2991/bst-16.2016.46

Babaev, V.R., L. Li, S. Shah, S. Fazio and M.F. Linton et al., 2010. Combined vitamin $\mathrm{c}$ and vitamin e deficiency worsens early atherosclerosis in apolipoprotein e-deficient mice. Arteriosclerosis Thrombosis Vascular Boil., 30: 1751-1757.

DOI: 10.1161/ATVBAHA.110.209502

Barnard, A.S. and M. Sternberg, 2007. Crystallinity and surface electrostatics of diamond nanocrystals. J. Mater. Chem., 17: 4811-4819.

DOI: $10.1039 / \mathrm{B} 710189 \mathrm{~A}$

Barnard, A.S., S.P. Russo and I.K. Snook, 2003. Structural relaxation and relative stability of nanodiamond morphologies. Diamond Relat. Mater., 12: 1867-1872. DOI: 10.1016/S0925-9635(03)00275-9

Buzea, E., F.L. Petrescu, L. Nănuț, C. Nan and M. Neacşa, 2015. Mechatronic system to determine the concentration of carotenoids. Analele Univ. Craiova Biol. Horticul. Tehn Prel Prod Agr. Ing. Med., 20: 371-376.

Chang, Y.R., H.Y. Lee, K. Chen, C.C. Chang and D.S. Tsai et al., 2008. Mass production and dynamic imaging of fluorescent nanodiamonds. Nature Nanotechnol., 3: 284-288. DOI: $10.1038 /$ nnano.2008.99

Chow, E.K., X.Q. Zhang, M. Chen, R. Lam and E. Robinson et al., 2010. Nanodiamond therapeutic delivery agents mediate enhanced chemoresistant tumor treatment. Sci. Transl. Med., 3: 73ra21-73ra21. DOI: $10.1126 /$ scitranslmed.3001713

Comerun, H.U., 1986. Six-year results with a microporous-coated metal hip prosthesis. Clin. Orthop. Relat. Res., 208: 81-83. PMID: 3522027

Covic, M., A. Covic, P.G. Tatomir and L. Segall, 2007. Manual de Nefrologie. 1st Edn., Polirom Publisher, pp: 448.

Danilenko, V.V., 2004. On the history of the discovery of nanodiamond synthesis. Phys. Solid State, 46: 595-599. DOI: 10.1134/1.1711431

Davis, P.A., S.J. Huang, L. Nicolais and L. Ambrosio, 1991. Modified PHEMA Hydrogels. In: High Performance Biomaterials, Szycher, M. (Ed.), Lancaster, PA, USA, p: 343-68.

Filmon, R., F. Grizon, M.F. Baslie and D. Chappard, 2002. Effects of negatively charged groups (carboxymethyl) on the calcification of poly(2-hydroxyethyl methacrylate). Biomaterials, 23: 3053-3059. DOI: $10.1016 / \mathrm{S} 0142-9612(02) 00069-8$

Frost, H.M., 1994. Wolff's law and bone's structural adaptations to mechanical usage: An overview for clinicians. Angle Orthod., 64: 175-188.

PMID: 8060014 
Frost, H.M., 1990. Skeletal Structural Adaptations to Mechanical Usage (SATMU): 2. Redefining Wolff's Law: The remodeling problem. Anat. Rec., 226: 414-422. DOI: 10.1002/ar.1092260403

Frost, H.M., 2004. A 2003 update of bone physiology and Wolff's law for clinicians. Angle Orthod., 74: 3-15. PMID: 15038485

Frost, H.M., 1964. Mathematical elements of lamellar bone remodeling.

Gramanzini, M., S. Gargiulo, F. Zarone, R. Megna and A. Apicella et al., 2016. Combined microcomputed tomography, biomechanical and histomorphometric analysis of the peri-implant bone: A pilot study in minipig model. Dental Mater., 32: 794-806.

DOI: 10.1016/j.dental.2016.03.025

Greiner, N.R., D.S. Phillips, J.D. Johnson and F. Volk, 1988. Diamonds in detonation soot. Nature, 333: 440-442. DOI: $10.1038 / 333440 \mathrm{a} 0$

Halpin, J.C. and J.L. Kardos, 1976. The halpin-tsai equations: A review. Polymer Eng. Sci., 16: 344-352. DOI: $10.1002 /$ pen.760160512

Holley, R.H., H.B. Hopfenberg and V. Stannett, 1970. Anomalous transport of hydrocarbons in polystyrene. Polymer Eng. Sci., 10: 376-382. DOI: 10.1002/pen.760100612

Jarre, G., Y.J. Liang, P. Betz, D. Lang and A. Krueger, 2011. Playing the surface game-Diels-Alder reactions on diamond nanoparticles. Chem. Commun., 47: 544-546. DOI: 10.1039/C0CC02931A

Kabra, B., S.H. Gehrke, S.T. Hwang and W. Ritschel, 1991. Modification of the dynamic swelling behaviour of pHEMA. J. Applied Polym. Sci., 42: 2409-2416.

Krueger, A. and T. Boedeker, 2008. Deagglomeration and functionalisation of detonation nanodiamond with long alkyl chains. Diamond Relat. Mater., 17: 1367-1370.

Krueger, A., J. Stegk, Y.J. Liang, L. Lu and G. Jarre, 2008. Biotinylated nanodiamond: Simple and efficient functionalization of detonation diamond. E Langmuir, 24: 4200-4204. DOI: 10.1021/la703482v

Kruger, A., Y.J. Liang, G. Jarre and J. Stegk, 2006. Surface functionalisation of detonation diamond suitable for biological applications. J. Mater. Chem., 16: 2322-2328. DOI: 10.1039/B601325B

Lai, L. and A.S. Barnard, 2011a. Modeling the thermostability of surface functionalisation by oxygen, hydroxyl and water on nanodiamonds. Nanoscale, 3: 2566-2575. DOI: 10.1039/C1NR10108K

Lai, L. and A.S. Barnard, 2011b. Stability of nanodiamond surfaces exposed to $\mathrm{N}, \mathrm{NH}$ and $\mathrm{NH}_{2}$. J. Phys. Chem. C, 115: 6218-6228.

DOI: $10.1021 /$ jp1111026

Marrelli, M., G. Falisi, A. Apicella, D. Apicella and M. Amantea et al., 2015. Behaviour of dental pulp stem cells on different types of innovative mesoporous and nanoporous silicon scaffolds with different functionalizations of the surfaces. J. Biol. Regulators Homeostat. Agents, 29: 991-997. PMID: 26753666
Mohan, N., C.S. Chen, H.H. Hsieh, Y.C. Wu and H.C. Chang, 2010. In vivo imaging and toxicity assessments of fluorescent nanodiamonds in Caenorhabditis elegans. Nano Lett., 10: 3692-3699. DOI: $10.1021 / \mathrm{nl} 1021909$

Montheard, J.P., M. Chatzopoulos and D. Chappard, 1992. 2-Hydroxyethyl Methacrylate (HEMA): Chemical properties and applications in biomedical fields. J. Macromol. Sci. Macromol. Rev., 32: 1-34. DOI: $10.1080 / 15321799208018377$

Nicolais, L., A. Apicella and C. de Notaristefano, 1984. Time-temperature superposition of n-hexane sorption in polystyrene. J. Membrane Sci., 18: 187-196. DOI: 10.1016/S0376-7388(00)85033-4

Osswald, S., G. Yushin, V. Mochalin, S.O. Kucheyev and Y. Gogotsi, 2006. Control of sp2/sp3 carbon ratio and surface chemistry of nanodiamond powders by selective oxidation in air. J. Am. Chem. Soc., 128: 11635-11642. PMID: 16939289

Ozawa, M., M. Inaguma, M. Takahashi, F. Kataoka and A. Krüger et al., 2007. Preparation and behavior of brownish, clear nanodiamond colloids. Adv. Mater., 19: 1201-1206. DOI: 10.1002/adma.200601452

Peluso, G., O. Petillo, J.M. Anderson, M. Ambrosio and L. Nicolais et al., 1997. The differential effects of poly(2-hydroxyethyl methacrylate) and poly(2hydroxyethyl methacrylate)/poly(caprolactone) polymers on cell proliferation and collagen synthesis by human lung fibroblasts. J. Biomed. Mater. Res., 34: 327-336. PMID: 9086402

Perillo, L., R. Sorrentino, D. Apicella, A. Quaranta and E. Gherlone, 2010. Nonlinear visco-elastic finite element analysis of porcelain veneers: A submodelling approach to strain and stress distributions in adhesive and resin cement. J. Adhesive Dentistry, 12: 403-413. PMID: 20157681

Petrescu, F.I.T. and K.J. Calautit, 2016a. About nano fusion and dynamic fusion. Am. J. Applied Sci., 13: 261-266. DOI: 10.3844/ajassp.2016.261.266

Petrescu, F.I.T. and K.J. Calautit, 2016b. About the light dimensions. Am. J. Applied Sci., 13: 321-325. DOI: 10.3844/ajassp.2016.321.325

Petrescu, F.L., E. Buzea, L. Nănuț, M. Neacşa and C. Nan, 2015. The role of antioxidants in slowing aging of skin in a human, Analele Univers. Craiova Biol. Horticul. Tehn. Prel. Prod. Agr. Ing. Med., 20: 567-574.

Petrescu, F.I.T., A. Apicella, R. Aversa, R.V. Petrescu and J.K. Calautit et al., 2016a. Something about the mechanical moment of inertia. Am. J. Applied Sci., 13: 1085-1090. DOI: 10.3844/ajassp.2016.1085.1090

Petrescu, R.V., R. Aversa, A. Apicella, S. Li and G. Chen et al., 2016b. Something about electron dimension. Am. J. Applied Sci., 13: 1272-1276. DOI: $10.3844 /$ ofsp. 10885 
Petrescu, R.V., R. Aversa, A. Apicella, F. Berto and S. Li et al., 2016c. Ecosphere protection through green energy. Am. J. Applied Sci., 13: 1027-1032. DOI: 10.3844/ajassp.2016.1027.1032

Petrescu, F.I.T., A. Apicella, R.V. Petrescu, S.P. Kozaitis and R.B. Bucinell et al., 2016d. Environmental protection through nuclear energy. Am. J. Applied Sci., 13: 941-946. DOI: 10.3844/ajassp.2016.941.946

Petrescu, R.V., R. Aversa, A. Apicella and F.I.T. Petrescu, 2016e. Future medicine services robotics. Am. J. Eng. Applied Sci., 9: 1062-1087. DOI: 10.3844/ajeassp.2016.1062.1087

Prashantha, K., K. Vasanth Kumar Pai, B.S. Sherigara and S. Prasannakumar, 2001. Interpenetrating polymer networks based on polyol modified castor oil polyurethane and poly(2hydroxyethylmethacrylate): Synthesis, chemical, mechanical and thermal properties. Mater, Sci., 24: 535-538. DOI: 10.1007/BF02706727

Schiraldi, C., A. D’Agostino, A. Oliva, F. Flamma and A. De Rosa et al., 2004. Development of hybrid materials based on hydroxyethylmethacrylate as supports for improving cell adhesion and proliferation. Biomaterials, 25: 3645-3653. DOI: $10.1016 /$ j.biomaterials.2003.10.059

Schrand, A.M., S.A.C. Hens and O.A. Shenderova, 2009b. Nanodiamond particles: Properties and perspectives for bioapplications. Crit. Rev. Solid State Mater. Sci., 34: 18-74. DOI: $10.1080 / 10408430902831987$

Schrand, A.M., S.A.C. Hens and O.A. Shenderova, 2009a. Nanodiamond Particles: Properties and Perspectives for Bioapplications. In: Safety of Nanoparticles: From Manufacturing to Medical Applications, Webster, T.J. (Ed.), pp: 159-187.

Schwartz-Dabney, C.L. and P.C. Dechow, 2003. Variations in cortical material properties throughout the human dentate mandible. Am. J. Phys. Anthropol., 120: 252-277. DOI: 10.1002/ajpa.10121

Shenderova, O., A. Koscheev, N. Zaripov, I. Petrov§ and Y. Skryabin $\S$ et al., 2011. Surface chemistry and properties of ozone-purified detonation nanodiamonds. J. Phys. Chem. C, 115: 9827-9837. DOI: $10.1021 /$ jp1 102466
Sorrentino, R., R. Aversa, V. Ferro, T. Auriemma and F. Zarone et al., 2007. Three-dimensional finite element analysis of strain and stress distributions in endodontically treated maxillary central incisors restored with diferent post, core and crown materials. Dent Mater., 23: 983-993. DOI: $10.1016 /$ j.dental.2006.08.006

Sorrentino, R., D. Apicella, C. Riccio, E.D. Gherlone and F. Zarone et al., 2009. Nonlinear visco-elastic finite element analysis of different porcelain veneers configuration. J. Biomed. Mater. Res. Part B Applied Biomater., 91: 727-736. DOI: 10.1002/jbm.b.31449

Töyräsa, J., T. Lyyra-Laitinena, M. Niinimäkib, R. Lindgrenc and M.T. Nieminenb et al., 2001. Estimation of the Young's modulus of articular cartilage using an arthroscopic indentation instrument and ultrasonic measurement of tissue thickness. J. Biomechan., 34: 251-256.

DOI: $10.1016 / \mathrm{S} 0021-9290(00) 00189-5$

Viecelli, J.A., S. Bastea, J.N. Glosli and F.H. Ree, 2001. Phase transformations of nanometer size carbon particles in shocked hydrocarbons and explosives. J. Chem. Phys., 115: 2730-2736. DOI: $10.1063 / 1.1386418$

Wolff, J., 1892. Das Gesetz der Transformation der Knochen. 1st Edn., A. Hirschwald, Berlin, pp: 152.

Xiao, J., G. Ouyang, P. Liu, C.X. Wang and G.W. Yang, 2014. Reversible nanodiamond-carbon onion phase transformations. Nano Lett., 14: 3645-3652. DOI: $10.1021 / \mathrm{nl} 5014234$

Yuan, Y., X. Wang, G. Jia, J.H. Liu and T. Wang et al., 2010. Pulmonary toxicity and translocation of nanodiamonds in mice. Diamond Relat. Mater., 19: 291-299. DOI: 10.1016/j.diamond.2009.11.022

Zhang, Q., V.N. Mochalin, I. Neitzel, I.Y. Knoke and J. Han et al., 2011. Fluorescent PLLA-nanodiamond composites for bone tissue engineering. Biomaterials, 32: 87-94. DOI: 10.1016/j.biomaterials.2010.08.090 